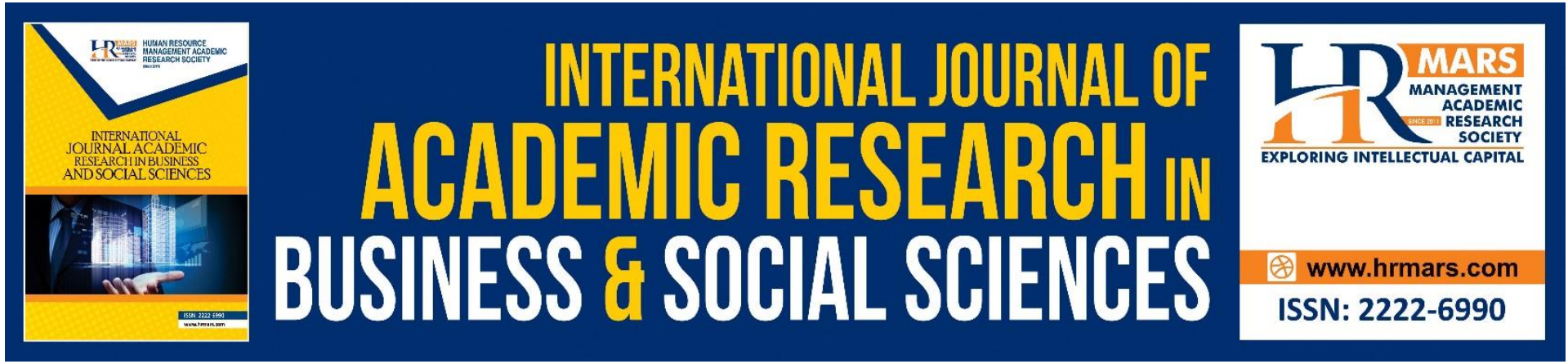

\title{
Participatory Management initiatives, Employees Commitment and Employees' Performance: An Empirical Study among Employees in Water Service Providers in Kenya
}

Elijah Ng'ang'a Njuguna, Jedidah Vika Muli, Lawrence Wainaina To Link this Article: http://dx.doi.org/10.6007/IJARBSS/v11-i8/10834 DOI:10.6007/IJARBSS/v11-i8/10834

Received: 11 June 2021, Revised: 18 July 2021, Accepted: 05 July 2021

Published Online: 26 August 2021

In-Text Citation: (Njuguna et al., 2021)

To Cite this Article: Njuguna, E. N., Muli, J. V., \& Wainaina, L. (2021). Participatory Management initiatives, Employees Commitment and Employees' Performance: An Empirical Study among Employees in Water Service Providers in Kenya. International Journal of Academic Research in Business and Social Sciences, 11(8), 1241-1262.

Copyright: (C) 2021 The Author(s)

Published by Human Resource Management Academic Research Society (www.hrmars.com) This article is published under the Creative Commons Attribution (CC BY 4.0) license. Anyone may reproduce, distribute, translate and create derivative works of this article (for both commercial and non-commercial purposes), subject to full attribution to the original publication and authors. The full terms of this license may be seen at: http://creativecommons.org/licences/by/4.0/legalcode

Vol. 11, No. 8, 2021, Pg. 1242 - 1262

Full Terms \& Conditions of access and use can be found at http://hrmars.com/index.php/pages/detail/publication-ethics 


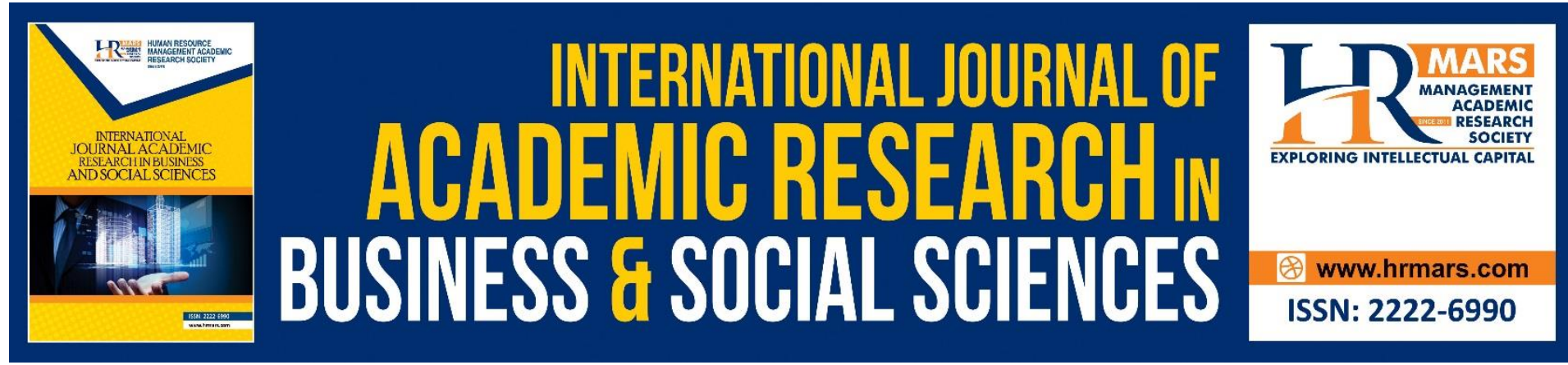

\title{
Participatory Management initiatives, Employees Commitment and Employees' Performance: An Empirical Study among Employees in Water Service Providers in Kenya
}

\author{
'Elijah Ng'ang'a Njuguna \\ School of Business: Kenyatta University \\ Email: talons.njuguna@gmail.com
}

\author{
${ }^{2}$ Dr. Jedidah Vika Muli(PhD), ${ }^{3}$ Dr. Lawrence Wainaina(PhD) \\ Lecturer: School of Business: Kenyatta University \\ Email: muli.jedidah@ku.ac.ke, Iwarwimbo@yahoo.com
}

\begin{abstract}
The aim of the study was to evaluate mediating influence of employees commitment on participatory management and employees' performance in water service providers in Murang'a County. The study was guided by the following objectives; a) To evaluate mediating effect of employees commitment on relationship between participatory management and employees' performance in selected water service providers in Murang'a County, (b) To assess the mediating effect of employee commitment on the relationship between Participatory Management; Predicting Employees' Performance. The study embraced an exploratory research design. A sample of 206 employees was selected from five water service providers namely: Murang'a Water and Sanitation Company Limited, Murang'a South Water and Sanitation Company Limited, Gatanga Water and Sanitation Company Limited, Gatamathi Water and Sanitation Company Limited and Kahuti Water and Sanitation Company Limited. Random sampling was applied in picking the respondents for the study. Self-administered questionnaires aided in collecting primary data and analyzed using both descriptive and inferential statistics. A pilot study was steered on data collection tool to pre-test it's validity prior to the main survey. Data reliability was measured using Cronbach's alpha coefficient. Statistical Package for Social Sciences (SPSS) version 21.0 was used to aid in coding, entry and analysis of data. conclusions and recommendations based on the findings were finally outlined. The study concludes that participatory management through consultative management, quality circles, representative participation and delegation is vital and significantly affects performance of employees in water service providers in Murang'a County, Kenya. However, the study finally concludes that employees commitment failed to mediate the relationship between participatory management and employees' performance. Employees
\end{abstract}


commitment therefore played insignificant part in enhancing effectiveness of participatory management to enhance employees' performance. Suggestion that employees commitment partially mediates the relationship between participatory management and employees' performance is a call to the management of water service providers in Murang'a County, Kenya to institute programmes that will ensure employees are committed to the job and organization as this is vital in enhancing effectiveness of participatory management.

Keywords: Participatory Management, Employees Commitment, Employees' Performance

\section{Introduction}

Employees commitment is an elementary matter of the proprietors of establishments and administration. It has direct relation with job performance influencing employees competitiveness. As commitment straight effect the employee performance it has massive importance. Employees commitment has engrossed the various practitioners and scholars of human resource management for it influences the organizational and employees' performance. Commitment is the kind of oath between an institution and employees where he is working (Kashefi 2013). This research will find the relation of commitment with other factors. Employee performance is a mutual perception, ability, and effort for tasks. Organizational objectives can be achieved due to good performance. Although, more efforts are required for enhancement of organizational performance. Employees' commitment improves the organizational competitiveness and employees' performance.

\section{Literature Review \\ Employees Commitment}

Globally employees commitment is viewed as a belief that connects feelings of organizational values and objectives with individual standards and objectives (Hakim, 2015). Employees commitment to a business entails creating a psychological bond between the employee and the organization (Lau, 2011). Employees commitment occasions three components: continuance commitment, normative commitment and affective commitment (Lambert \& Keena, 2015). Conferring with Kashefi (2013) employees passionate affection remains the worker's pillar to affectively offer commitment in resonating and engrossing in a firm. Normative commitment is a sentiment of compulsion to remain in an organization categorized as universal value of reliability and obligation. Continuance commitment is the preparedness to endure in an organization because of special venture such as close operational interactions with co-workers, superannuation and profession reserves. Kiiza and Picho (2015) argues that affective commitment originates after a demonstrative linking to the group and is regularly complex to job practices. It evolves when an worker is tangled in pinpointing the importance of his or her identity from the establishment.

\section{Participatory Management}

Participatory management is outlined as a human right in the United Nations 1986 affirmation of right to progress which is based on a number of principles including consultative management, delegated power and its implication on job execution and the process of representation (Hamm, 2011). Employees participation is categorized as direct and indirect. Direct participation may take place through goal-setting plans by individuals, consultations, forming employees into quality circles, and delegating to others. Indirect involvement includes use of employee's selected agents or shop stewards (Noah, 2008). 
As witnessed by Robert, (2011) participatory management help to advance an accomplishing philosophy that boosts extraordinary performance in ranges for example production and effectiveness of employees and ultimately influence toward shareholder value. Employees form groups such as unions and quality circles to decide objectives to be achieved by developing joint actions (Aronowitz et al., 2015). According to Bryson and Freeman (2012) participating in management takes stratagem to attain a more vigorous and competent management by dividing responsibilities between leaders and the resource users. According to Pritchard (2008); Osman (2011) and cited in Boeddeker (2011) participatory management can be classified in the following categories: consultative management, delegation and team based representation. Chen and Tjosvold (2011) asserts that participatory management enhances team work and increase decision making that it is accomplished by group participation. Thus study embraced the following participatory management initiatives: consultative management, quality circles. representative participation and delegation.

\section{Employees' Performance}

According to Hitt (2011) insubstantial assets are further likely than noticeable resources to yield a competitive advantage to promote employees' performance. This was supported by David (2014) that a firms' employees' performance is influenced by its capacity to protect and use the intangible resources it generates which could be productivity, effectiveness and timeliness of output. Companies are forced to compete and act professionally to have capable employees to help them create competitive advantage in service delivery (Mwita, 2012). Jena and Rautaray (2010) argues that performance of employees is about the results obtained from employees after being allocated a certain task within the organisations. Frese(2011) contends that employees' performance indicators involve effective service provision, high output, service value, and aptness of output. Yang (2008) on individual performance proclaims success by accomplishing the prospects of the shareholders. In line with Memari (2013) employees' performance is greatly felt where reward of performance is practiced through participation. Productivity of employees is highly influenced by attendance, which is significant to guarantee justifiable performance to complete the obligatory responsibilities and evade administration conflict and reduced performance value of employees participation in the system (Ruokalanien, 2011).

According to Cardy (2014) performance is essentially the result of how input is well and timely transformed into output to demonstrate the ultimate efficiency in front of superiors, consumers, proprietors and co-workers. Tohidi (2010) argues that service effectiveness is the capacity of workforce to meet the estimated intentions or target. Timeliness of output is the characteristic of services with aptitude to gratify the quantified or inferred needs (Armstrong, 2010).

Employees outcomes as well as behaviour that enhances effectiveness are some of the measures that Allen and Collins (2013) proposed that can measure performance of employees. They further argues that individuals skills, knowledge and work experience contributes significant on employees' performance. According to Kagaari et al (2010) employees' performance narrows down to productivity, speed of delivery and effectiveness. Employees remain a central reserve therefore imperative to augment the involvement of employees to the business and to understand determinants of employees' performance (Elnaga \& Imran 2013). Employees' performance is aimed to enhance institutional capacity through desirable results and give direction to any firm or organization growth creating room for expansion (Mwita, 2012). 


\section{Statement of the Problem}

To clearly articulate vision twenty thirty(2030) GoK has acknowledged employees to be key in fast tracking the realization of the vision by improving access to clean and reliable water. Commitment, motivates employees to work for the good of the organization. There are various studies that discuss organizational commitment, and employees' performance, yet it is hardly to see the research done on interrelationship between employess commitment and employees' performance specifically in Kenya context. Thus, the paper is an attempt to fill this gap in the literature. The GoK through WASREB (Water Services Regulatory Board) has implemented several reforms. They include the Water Act (2002) and the Water Act (2016) which calls for inclusion of employees in articulating this goal. Despite these initiatives by the government water service providers in Murang'a County have faced employees' performance related challenges (Njanja \& Njagi, 2013).

According to Mawia (2017) the focus of the study on commitment explored the understanding of commitment's antecedents, processes, and its consequences. Antecedents of commitment may be explained in various situations in the workplace such as affective commitment. This paper intends to explore more on this phenomenon. Water services regulatory impact report (2018) specified that the administration might be excluding employees as associates of the firms by failing to promote their commitment affecting their performance. This study aims to cover this gap by clearly using commitment as a mediating variable in the study. A study by (Wasreb, 2017) on mediating effect of organizational commitment in water sector in Kenya, dwelt so much on leadership type but failed to articulate clearly effects of commitment on employees' performance. A gap this study aims to bridge. Consequently, it is important for this research to appreciate the relationship between participatory management initiatives, employees' commitment and employees' performance.

\section{Research Objectives}

i. To evaluate mediating effects of employees commitment on relationship between participatory management and employees' performance in selected water service providers in Murang'a County, Kenya.

ii. To assess the mediating effect of employee commitment on the relationship between Participatory Management; Predicting Employees' Performance.

\section{Research Hypotheses}

$\mathrm{H}_{01}$ : Employees commitment causes no significant mediating influence on the relationship between participatory management and employees' performance in selected water service providers in Murang'a County, Kenya.

\section{Purpose of the Study}

The purpose of the study was to evaluate the influence of participatory management initiatives, employess commitment on employees' performance in selected water service providers in Murang'a County, Kenya. The study aim was to identify the level of commitment and non-commitment employees of the water service providers and also advise on inspiration approaches according to their commitment echelons. This study's findings indicated that if well implemented, commitment together with other variables can have effect on performance of employees. Furthermore, through the findings the companies identify the 
training needs for workers exhibiting low commitment on their occupations as necessary. The need to conduct the study was to evaluate how commitment can influence performance as an important factor towards improvement of performance among water company employees. The results show that commitment jointly with other variables influence the employees' performance in water sector. The purpose also presented the need to show how employees are willing to devote and stay in water companies to accomplish the objectives of job performance because they have same goals and values.

\section{Theoretical Review}

The study was anchored on the following theories: Role theory and Resource-Based View supported by two other models which include: Servqual Model and Collegial Model.

\section{The Role Theory}

Katz and Kahn (1966) are credited in articulating this theory which positions and indicate that the part personalities inhabit at work and in different place occurs relatively to additional individuals. Consequently, society partake prospects about the individuals' duty ones they honor these projections have capably performed the role. According to Hopkins (2011) the role theory is often used to scrutinize numerous characteristics of employees' performance. In any enactment of a role, performance becomes the creation of the form individuals for instance the operational framework or influence applied from high to low level or elsewhere in the organization and their own services, competencies and assertiveness (Devaro, 2008).

\section{Resource -Based View}

The perspective is initiated and primed through (Penrose, 1959) work. Barney (2007) postulates by arguing about institution improving reasonable plus by not solitary obtaining but likewise mounting, tapping together, and excellently positioning its bodily, social, and organizational possessions. In practice this always put in exceptional worth and challenges the opponents to imitate. Wernerfelt (2004) asserts that the perspective conditions create modest benefit originates within inward possessions a corporate preserve. Resource based view perspective speculates that corporations accomplish justifiable competitive benefit if by holding vital resources by commendably position these possessions in their selected arcades (Barney, 2007). The theory hypothesizes that an organizations' performance hang on its precise capitals and competences (Fotopoulos, Kafetzopoulos \& Psomas, 2012).

\section{Servqual Model}

This model remain the work of Zeithml, Valarie and Berry (1985) a team of academic researchers to measure quality of service and productivity in the service sector. The Servqual model assumes that an unswerving affiliation occurs between service aptness, service delivery and service effectiveness According to Kumar (2009) the model is tagged and anchored on the following scopes: Tangibility which is physical facilities; apparatus, and attendance of personnel. Reliability encompassing capacity to realize service consistently and precisely. Responsiveness which involves the willingness towards assisting customers and staff in rendering timely services. Assurance which stands for employees courtesy plus the talent to motivate self-assurance and empathy comprising of considerate personalized attention the establishment delivers. 


\section{The Collegial Model}

The theory is initiated through the work of (Davis, 1967). The term 'collegial' refers to a decision-making framework with structures designed to achieve specific goals in a predictable manner with working together cooperatively (Newsrom, 2011). This model comprises all those supports emphasizing that influence and policymaking ought to be collective or among all members of an organization. The autonomous component of official representation rests on the commitment shown by members to their population (Bush, 2007). This model symbolizes a crew notion. Additionally, its valuable in participatory situation, imaginative effort and substantial work liberty. It involves the organization shaping a sensation of partnership with workers.

\section{Empirical Literature}

Participatory management is outlined as a human right in the United Nations 1986 affirmation of right to progress which is based on a number of principles including consultative management, delegated power and its implication on job execution and the process of representation (Hamm, 2011). Employees participation is categorized as direct and indirect. Direct participation may take place through goal-setting plans by individuals, consultations, forming employees into quality circles, and delegating to others. Indirect involvement includes use of employee's selected agents or shop stewards (Noah, 2008). In this journal the participatory management initiatives are outlined and the results shown as captured by the study are: consultative management, quality circles, representative participation and delegation whereas employees' performance will be measured by the use of employees productivity, timeliness of output and effectiveness.

\section{Research Methodology}

The research design adopted was a mixture of explanatory and exploratory designs. The combination is key since it delivers a precise and binding illustration of the variables pertaining or applicable providing the answers to the main research questions. According to Cooper and Schindler (2011) explanatory research focuses on why questions. In answering the why questions, the study involved developing causal effect explanations. The target population included 357 employees in the water service providers in Murang'a County, Kenya. The study focused on the management and non-management employees. These employees included top management, middle level staff and lower cadre staff. The distribution of target population of the study is shown in Table 1.

Table 1

Target Population

\begin{tabular}{llllllll}
\hline No & Cadre & Murang'a & Gatamathi & Gatanga & $\begin{array}{l}\text { Murang'a } \\
\text { S. }\end{array}$ & Kahuti & Total \\
\hline 1 & Top Management & 9 & 7 & 8 & 9 & 8 & 41 \\
2 & $\begin{array}{l}\text { Middle } \\
\text { Management }\end{array}$ & 30 & 25 & 23 & 34 & 24 & 114 \\
3 & $\begin{array}{l}\text { Lower level } \\
\text { Total }\end{array}$ & 50 & 32 & 33 & 52 & 35 & 202 \\
\hline
\end{tabular}

Source: Murang'a County Human Resource Matrix Database (2019) 


\section{Sample Design and Size}

The research used randomly selected sample size since it's easy in application and taken as the accurate representation of the larger population. According to Kasomo (2006) a sample holds features existing in the target population and have independent possibilities of selection. Based on the random sampling formula, the study, picked a sample size of 206 as shown in Table 2 below.

Table 2

Sample Size

\begin{tabular}{llll}
\hline Cadre & Total population & Sample size & Percentage \\
\hline Top level- Management employees & 41 & 23 & 11.6 \\
Middle- level management employees & 114 & 65 & 32.1 \\
Lower - level management employees & 202 & 114 & 56.3 \\
Total & $\mathbf{3 5 7}$ & $\mathbf{2 0 6}$ & $\mathbf{1 0 0}$ \\
\hline
\end{tabular}

Source: Researcher (2019)

\section{Instruments for Data Collection}

A combination of both primary and secondary data was employed in gathering data. A Semistructured questionnaire aided in primary data collection. A documents evaluation list aided in collecting secondary data.

\section{Validity and Reliability of Data Collection Instruments}

Sekaran (2013) urgues that validity denotes exactness and significance of interpretations made founded on results obtained. Suggestions were made and likened to the prevailing theories. Developed instruments was presented to the supervisors and the research specialists in the relevant school to assess the usability and aptness of the content, precision and tolerability of development of the instrument from a research perspective. The study terms operationalization was used to ensure construct validity.

Orodho (2009) argues that the level of the degree an instrument yields similar outcome repeatedly constitutes reliability. Reliability testing involved presenting to the employees of Thika Water and Sanitation Company limited with twenty (20) selected respondents not included in the final sample size for piloting. to determine the internal consistency of the research instruments reliability computed using the versally accepted Cronbach Alpha coefficient beyond 0.7 .

\section{Data Collection Procedures}

Data was collected through the process of obtaining consent letter from the National Commission for Science, Technology and Innovation (NACOSTI). The questionnaires distribution to respondents was done by the human resource management department.

\section{Data Analysis and Presentation}

Questionnaires codding then feeding them to the SPSS computer software which summarizes data about a single variable was done as argued and analyzed. Frequencies, mean, standard deviation were used to analyze descriptive data. The inferential pointers aided on how to analyze qualitative figures with regression scrutiny being applied. The presentation of the findings was largely done using tables and figures to indicate frequency and percentage spread. 


\section{Research Findings and Discussions}

The subsequent extents covered under elementary data: response rate, respondents' gender, age, highest level of education qualification, current position held in the company and number of years in the current position.

\section{Response Rate}

This study considered 357 employees being targeted population with 206 employees captured as the sampled size grouped into the following strata: top management, middle management and lower level employees of the five (5) Murang'a County Water Service Providers. The total number of questionnaires which were administered to respondents in the three strata was 206. Overall, 163 respondents duly filled and returned the questionnaire representing a response rate of $79.13 \%$ deemed acceptable to conduct statistical analysis (Mugenda et al., 2008). On the other hand, 43 questionnaires that were incomplete or not responded to were rejected. The busy schedules of the respondents accounted for the unreturned questionnaires. According to Saunders, Lewis and Thornhill (2007), a response rate of above $50 \%$ is justifiable for conducting statistical analysis while Ghauri (2005) asserts that return rates of above $50 \%$ are satisfactory. Based on the recommendations of the various scholars, the $79.13 \%$ was appropriate to conduct statistical analysis and draw inferences of the study objectives. Figure 1 indicates the outcomes.

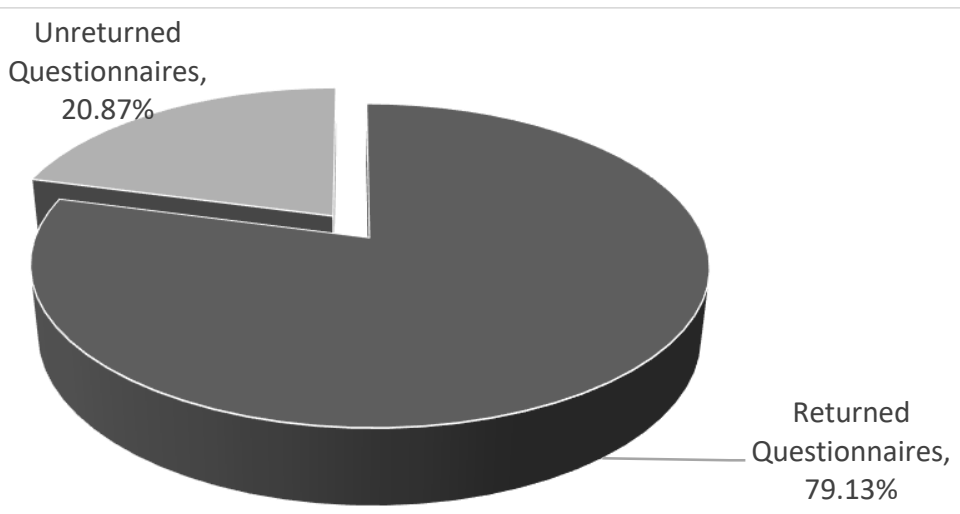

Figure 1. Response Rate

Source: Research Data (2019)

\section{Age of the Respondents}

The study sought to determine the age bracket of the respondents and therefore requested them to indicate their age category. From the findings as indicated in Figure 2, the largest proportion of the respondents represented by $44.2 \%$ were aged between 31 to 40 years followed by $22.7 \%$ who were aged between 25 to 30 years and further $20.2 \%$ who were aged between 41 to 50 years. Only $3.1 \%$ of the respondents were aged above 50 years. 


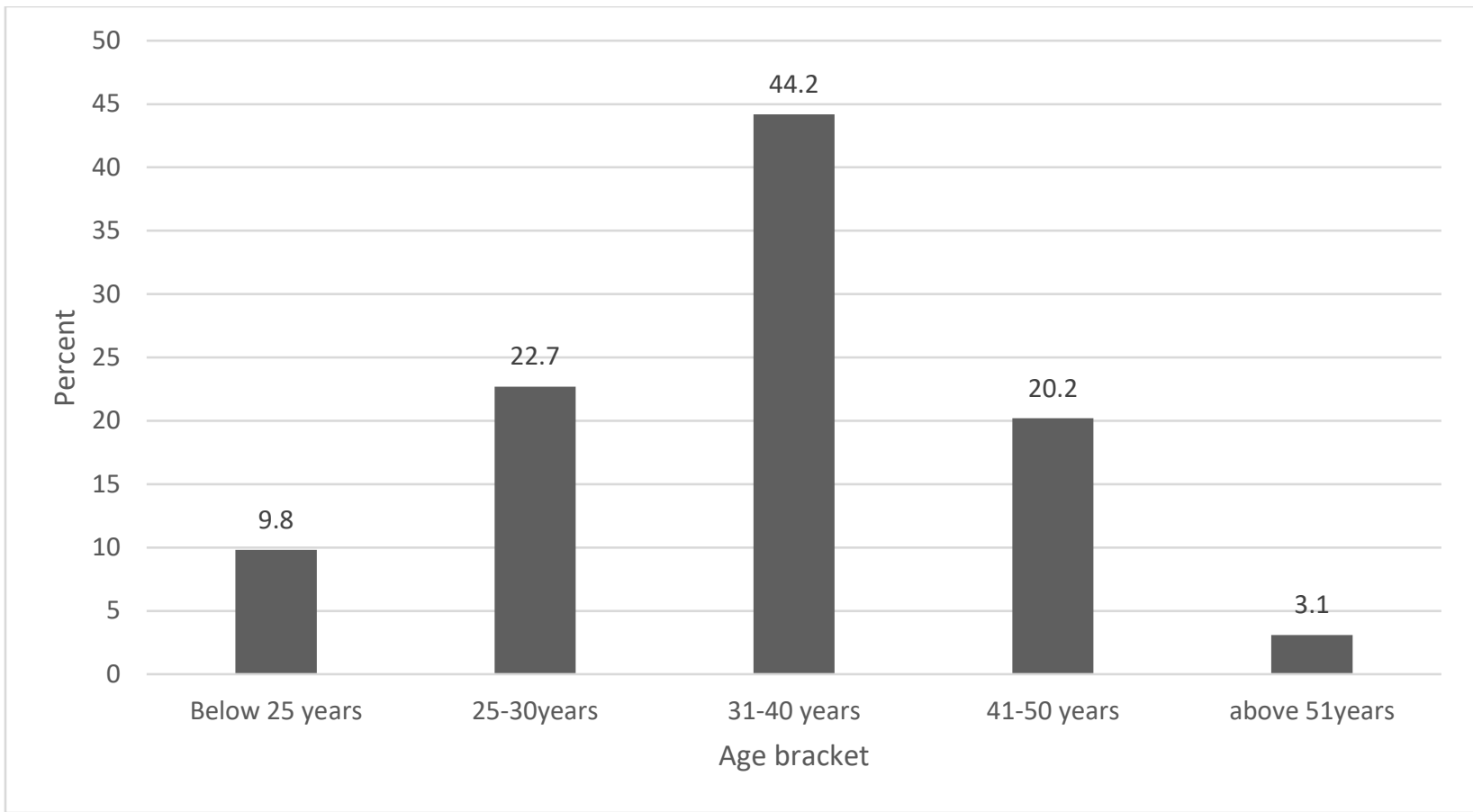

Figure 2. Age of the Respondents

Source: Research Data (2019)

\section{Current Position of the Respondents and Years of Service}

To further confirm the results, the study cross tabulated the current position of the respondents and years of service against their age and as shown in Table 3, the largest proportion of respondents (11) who occupied top level of management were aged above 40 years while the largest proportion of respondents (14) who had worked in the current position for more than 9 years were also above 40 years.

Table 3

Cross Tabulation of Age and Current position; Years of service

\begin{tabular}{lllllll}
\hline Current position & Age bracket & & & & \multicolumn{2}{c}{ Total } \\
\hline & Below 25 years & $\mathbf{2 5}$-30years & $\mathbf{3 1 - 4 0}$ years & $\mathbf{4 1 - 5 0}$ years & Above 51years \\
Top level management & 2 & 1 & 7 & 8 & 3 & 21 \\
Middle level & 9 & 10 & 35 & 17 & 0 & 71 \\
Lower level cadre & 5 & 26 & 30 & 8 & 2 & 71 \\
Total & $\mathbf{1 6}$ & $\mathbf{3 7}$ & $\mathbf{7 2}$ & $\mathbf{3 3}$ & $\mathbf{5}$ & $\mathbf{1 6 3}$ \\
\hline Years of service & & & & & & \\
\hline 3 or less & 12 & 18 & 1 & 2 & 1 & 34 \\
4-6 & 2 & 19 & 20 & 12 & 0 & 53 \\
7-8 & 1 & 0 & 45 & 9 & 0 & 55 \\
$9-11$ & 1 & 0 & 6 & 9 & 3 & 19 \\
More than 12 & 0 & 0 & 0 & 1 & 1 & 2 \\
Total & $\mathbf{1 6}$ & $\mathbf{3 7}$ & $\mathbf{7 2}$ & $\mathbf{3 3}$ & $\mathbf{5}$ & $\mathbf{1 6 3}$ \\
\hline
\end{tabular}

Source: Research Data (2019) 


\section{Respondent Years of Service}

In this regard, the results showed that the largest proportion of the sample, $33.7 \%$, had worked in the company for a period of 7 to 8 years while $32.5 \%$ indicated that they had worked for a period of 4 to 6 years with a further $20.9 \%$ indicating that they had worked in the company for 3 years or less. Only $12.9 \%$ of the respondents indicated that they had worked in the company for a period of more than 9 years. The results imply that majority of the respondents had worked in the company long enough to understand it's management dynamics. that most of the interviewees were experts who had managed for long therefore provided correct data management dynamics in the company. According to Aosa (2011) long tenured employees are likely to participate in the management arrangement of a firm. The findings imply that most of the interviewees were experts. The findings are presented in Figure 3.

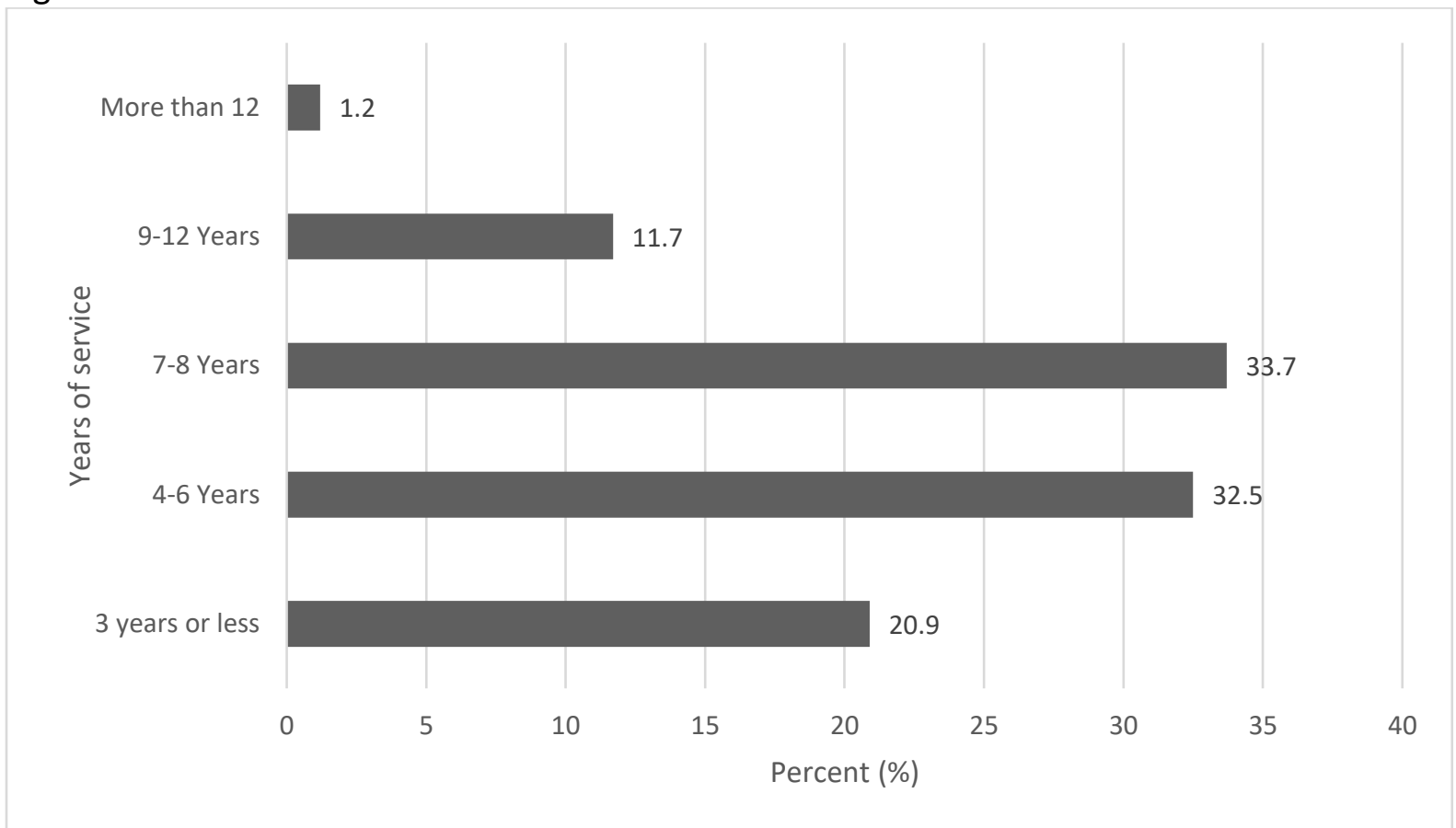

Figure 3. Respondent Years of Service

\section{Source: Research Data (2019)}

\section{Educational Level of the Respondents}

From the findings in Figure 4, it was established that the largest proportion of the sample, $38.7 \%$, indicated college Diploma as the utmost educational achievement with a further $23.9 \%$ holders of University Degrees while $4.9 \%$ had post graduate education qualification. However, $31.9 \%$ of the respondents indicated that they had high school level of academic qualification. The findings imply suitability of the respondents for the study as they had adequate level of education to read and understand the contents of the research instrument. 


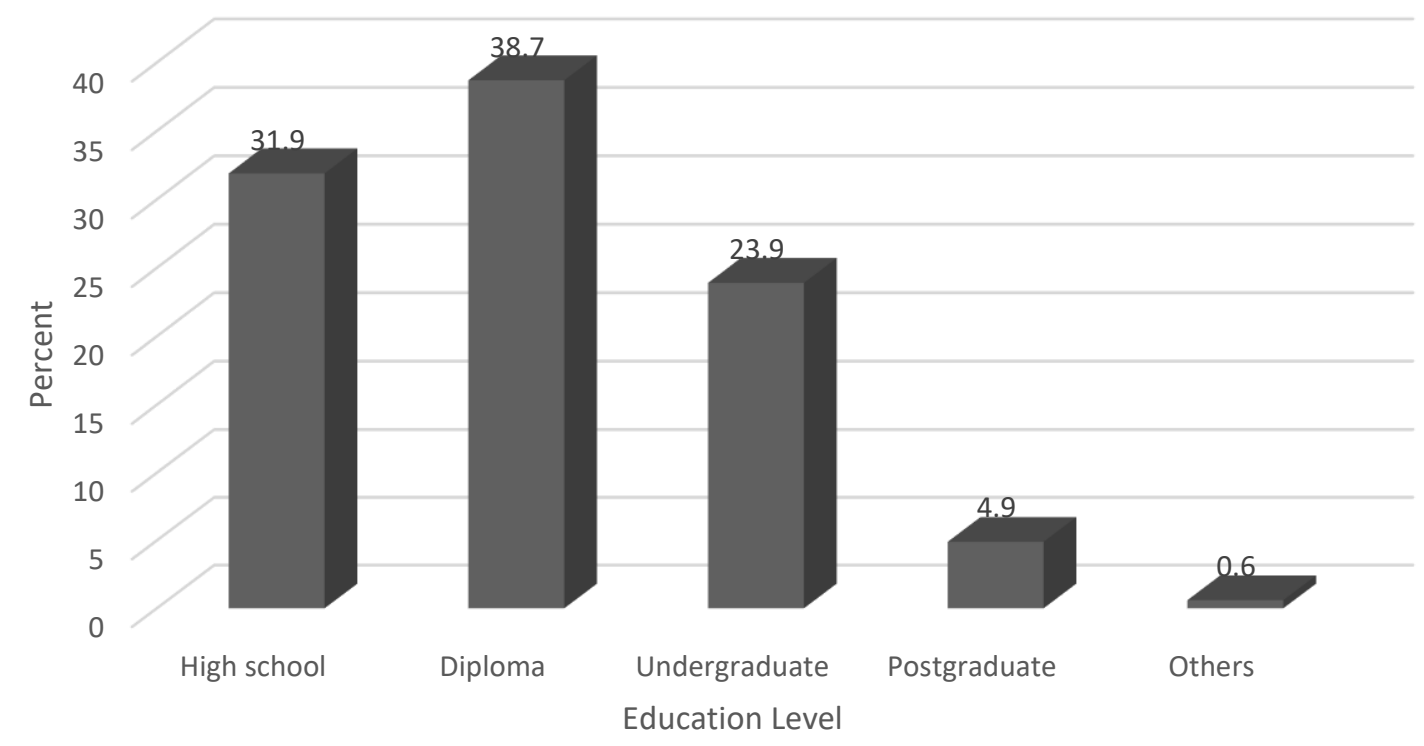

Figure 4 . Educational Level of the Respondents

Source: Research Data (2019)

\section{Gender of the Respondents}

From the findings as indicated in Table 4 male respondents made up 46\% of the sample while $54 \%$ were female. This is an indication that both genders were involved in this study and thus the findings of the study did not suffer from gender bias.

Table 4.

\section{Gender of Respondents}

\begin{tabular}{lll}
\hline Gender & Frequency & Percent \\
\hline Female & 88 & 54 \\
Male & 75 & 46 \\
Total & $\mathbf{1 6 3}$ & $\mathbf{1 0 0}$ \\
\hline
\end{tabular}

Source: Research Data (2019)

\section{Consultative Management on Employees' Performance}

Respondents were requested to specify the level of their agreement with various statements regarding consultative management in the company with the aim of establishing whether the embraced consultative management. The findings indicate that the largest proportion of the sample, $36.4 \%$ and mean value 3.91 agreed that their supervisor considers attitude surveys outcome always while a further $33.3 \%$ strongly agreed. On whether there exists information sharing during meetings with the supervisor and employees regularly use suggestion plans, the outcomes revealed that the largest fraction of the sample, $45.7 \%$ (mean=3.95) and $39.8 \%$ (mean $=3.75$ ) respectively, agreed to the statements.

The results also indicated that a larger proportion of the sample represented by $29.2 \%$ and a mean of 3.61 agreed that employee attitude surveys in the organization are regarded highly whereas $41.9 \%$ agreed that supervisor are always ready to listen to the juniors' views and proposals confirmed by a mean of 3.73. It was further established that respondents agreed that immediate supervisor suggests methods to advance group's production, $38.9 \%$ and mean 
value 3.7, and that seniors encourage work team participants to solve problems jointly as represented by $37.7 \%$ and mean of 3.83 .

A mean of 3.73 also confirmed that the largest proportion of the sampled respondents agreed that managers openly discusses employee career development in meetings. Regarding the statement whether top management inspires work team members to interchange material information with one another, the largest percentage of the sample, 41.1 and a mean of 3.92 agreed. It was also established that the largest proportion of the sample as represented by $39.8 \%, 34.2 \%$ and $37.7 \%$ respectively agreed that outcomes completed in the joint consultative gatherings are communicated in good interval to workers, employees always know when changes that affect their job are conducted and that staffs are briefed with response once they give suggestions. The findings in this section generally imply that water service providers in Murang'a County practice consultative management by sharing pieces of information with employees with an aim of improving employees' performance.

\section{Quality Circles on Employees' Performance}

The findings demonstrate that the major percentage of the sample represented by $34.8 \%$ and $33.5 \%$ strongly agreed and agreed respectively that they would join alternative circle in case they were moved to another section or area of work responsibility. The findings are confirmed by a mean of 3.88. Similarly, the largest percentage, $38.50 \%$ and $37.50 \%$ respectively, agreed that they shared responsibilities with colleagues who are quality circle members in one's department and that the top management has laid down supportive policies to promote quality circles.

Regarding the statement that opportunities given through circles increase material information distribution between employees, $43.5 \%$ of the respondents who represented the largest proportion agreed as confirmed by a mean of 3.68. Moreover, respondents averagely agreed that their relationship with work group was better than it had been in the past, $34.40 \%$, whereas $42.5 \%$ and a mean of 3.68 agreed that quality circles assist development of employees' skills in needs analysis. It was also established that respondents agreed that quality circles have helped employees to be more active which improve their performance, $37.50 \%$, members of the circles meet as a group to foster our circle efforts, $34.20 \%$ and that quality circles enhance the productivity of the employees than ever before as indicated by a mean of 3.99. The findings in this section are an indication that employees in water service providers in Murang'a County, Kenya participate in quality circles to enhance their performance.

\section{Representative Participation on Employees' Performance}

Findings further show majority agreed that personnel are represented by a chosen co-worker at the management board as shown by $39.5 \%$ and a mean of 4.04 . Further, respondents agreed that they remained strong affiliate of a work team in the organization, $54.70 \%$, and a participant of quality administration work squad in their department, $34.80 \%$ and mean value 3.89. A mean of 3.74 also showed that respondents agreed that a council of elected workers' representatives exist in the organization while $42.6 \%$ and mean 4.07 strongly agreed that there is a trade union representative in the organization. Regarding the statement that workers in the firm feel sufficiently represented at the joint union/management committee, the largest proportion of the sample, $40.7 \%$ and mean 3.73 agreed.

It was also indicated that there is a trade union representative on staff matters whereby $39.5 \%$ and mean 3.81 agreed. However, respondents averagely agreed that representation in 
numerous structures rises the self-esteem of employees, $38.30 \%$ and mean 3.72 , and that a pleasant working association by the work councils and the management in the organization exits as shown by $38.9 \%$ and a mean of 3.67. Moreover, the results show that respondents agreed that decisions made in meetings with representatives are shared in good time to employees, $42.00 \%$, and that representation in verdict making structures increases workers obligation to the organization, $40.10 \%$ and mean 3.89. The results presented in this section confirm that employees in Water Service Providers in Murang'a County are involved in representative participation and that the companies strive to ensure employee representation at all level of management and structures.

\section{Delegation on Employees' Performance}

Respondents were asked to indicate their agreement or otherwise with various statements regarding delegation in the company. The findings presented illustrate that the biggest percentage of the Sample represented by $44.7 \%$ strongly agreed that their supervisor delegates and assigns duties and responsibilities to capable employees. It was also established that respondents agreed that they are afforded freedom to make decisions and account for results as represented by $50.30 \%$ and an average of 3.85 .

This outcomes further show participants agreed they regularly design work schedules without waiting for managers to instruct them, they value input from employees mandated by the supervisor to regulate how work is executed and that they acknowledge authority given by responding with actions as shown by respective means of 3.84, 3.99 and 4. Regarding the declaration that delegation accelerates decision making process among employees in this firm, $48.4 \%$ of the respondents agreed whereas $26.7 \%$ strongly agreed. On the statement delegation help one's colleagues gain exposure and growth, the largest percentage of the sample, $42.9 \%$ agreed, similarly, results show that $54.4 \%$ agreed that their supervisor inspires them to guide what happens in their division.

The results additionally show that respondents agreed that delegation makes them to adopt with different conditions at this organization, $40.40 \%$ and mean 4.11 , and that delegation offers them a chance to depend on themselves in attaining work performance, $42.50 \%$. The results generally imply that delegation is practised in water service providers in Murang'a County to ensure that employees benefit and grow from undertaking specific duties and responsibilities.

\section{Employees Commitment}

In the objective aimed at evaluating the mediating effect of employees commitment on relationship between participatory management and employees' performance selected water services providers in Murang'a Couny, Kenya. Respondents replied to various constructs of employees commitment to show level of agreement based on a 5-point Likert scale where Strongly Agree $=5$, Agree $=4$, Averagely Agree $=3$, Disagree $=2$ and Strongly Disagree $=1$ was adopted. The findings as presented in Table 1 show that 38.6\% representing the largest proportion of the respondents agreed that they would be pleased to devote the remaining part of their profession time in the company confirmed by a mean of 4.05 whereas majority, $50.3 \%$ agreed that they appreciate deliberating about the organization with the public. Similarly, $44.2 \%$ of the sample agreed that they feel contented to partake an occupation in the organization continually since their values are shared while $33.5 \%$ strongly agreed that they certainly felt as though the firms' problems were also theirs. 
Regarding the claim that if one had not invested presently too much in the company, they would plan to be employed elsewhere, $31.6 \%$ agreed while $22.2 \%$ disagreed. Moreover, respondents strongly agreed that they thought they could certainly become as committed to another organization as they remained in the current one whereas $39 \%$ agreed that they were eager to pledge unlimited energy and support to make the company successful. Similarly, $38.7 \%$ representing the largest percentage agreed that they felt it would be a big let-down to colleagues in case they left the firm to join a different one. At same time it was noted that most of respondents, $45.8 \%$ and mean 1.8 , strongly disagreed that they do not feel passionately dedicated to the company.

In addition, deductions show most of interviewees averagely consented that company bears a countless deal of individual sense for them as represented by $39.6 \%$ and a mean of 3.38 . Respondents also strongly disagreed that they lack a robust sense of belonging to the firm, 47.70\% whereas $56.3 \%$ agreed that parting with the company would remain a wrong judgement considering how it had inspired them. The findings in this section generally indicate the respondents were committed to the company and to their job. A study by Salim (2017) indicated that employees commitment subscales holds a significant influence on work performance proportions regarding output of employees.

Table 5: Employees Commitment Results

\begin{tabular}{|c|c|c|c|c|c|c|c|}
\hline Declaration & SD & D & $\mathbf{A A}$ & A & SA & Mean & $\begin{array}{l}\text { Std. } \\
\text { Dev }\end{array}$ \\
\hline \multicolumn{8}{|l|}{ I would be pleased to devote the } \\
\hline remain part of my profession in & & & 22.2 & 34.2 & 38.6 & & \\
\hline this company & $1.3 \%$ & $3.8 \%$ & $\%$ & $\%$ & $\%$ & 4.05 & 0.94 \\
\hline I appreciate deliberating about this & & & 24.8 & 50.3 & 21.7 & & \\
\hline organization with public & $0.0 \%$ & $3.2 \%$ & $\%$ & $\%$ & $\%$ & 3.90 & 0.77 \\
\hline \multicolumn{8}{|l|}{ I feel contented to partake an } \\
\hline continually since my values are & & & 28.8 & 44.2 & 25.6 & & \\
\hline shared & $0.0 \%$ & $1.3 \%$ & $\%$ & $\%$ & $\%$ & 3.94 & 0.77 \\
\hline I certainly have feelings as though & & & 27.2 & 32.9 & 33.5 & & \\
\hline the firms' difficulties remain mine. & $1.3 \%$ & $5.1 \%$ & $\%$ & $\%$ & $\%$ & 3.92 & 0.96 \\
\hline If hadn't invested presently too & & & & & & & \\
\hline much in this company, I would & & 22.2 & 21.5 & 31.6 & 20.9 & & \\
\hline plan to be employed elsewhere & $3.8 \%$ & $\%$ & $\%$ & $\%$ & $\%$ & 3.44 & 1.16 \\
\hline \multicolumn{8}{|l|}{$\begin{array}{l}\text { I think I could certainly become as } \\
\text { committed to another }\end{array}$} \\
\hline organization as I remain to this & & 12.2 & 27.6 & 28.8 & 29.5 & & \\
\hline one & $1.9 \%$ & $\%$ & $\%$ & $\%$ & $\%$ & 3.72 & 1.08 \\
\hline \multicolumn{8}{|l|}{ I do not feel similar to an associate } \\
\hline member of the family at this & & 23.9 & 19.4 & 24.5 & 26.5 & & \\
\hline organization & $5.8 \%$ & $\%$ & $\%$ & $\%$ & $\%$ & 3.42 & 1.27 \\
\hline \multicolumn{8}{|l|}{ I am eager to position unlimited } \\
\hline pledge of more energy to support & & & 30.5 & 39.0 & 27.9 & & \\
\hline this company to be successful & $0.6 \%$ & $1.9 \%$ & $\%$ & $\%$ & $\%$ & 3.92 & 0.85 \\
\hline
\end{tabular}


I feel it a big let-down to my

colleagues in case I leave the firm

and join different one

I do not feel passionately

dedicated to this company

This institution bears a countless

deal of individual sense for me

I lack a robust sense of belonging

to this firm

Parting with this group remains a

wrong judgement for me

considering how it has inspired me

I am not scared of whatever might

\begin{tabular}{|c|c|c|c|c|c|c|}
\hline & 13.5 & 29.7 & 38.7 & 16.1 & & \\
\hline $1.9 \%$ & $\%$ & $\%$ & $\%$ & $\%$ & 3.54 & 0.98 \\
\hline 45.8 & 40.6 & & & & & \\
\hline \multirow[t]{2}{*}{$\%$} & $\%$ & $5.2 \%$ & $4.5 \%$ & $3.9 \%$ & 1.80 & 1.00 \\
\hline & 11.4 & 39.6 & 27.5 & 16.1 & & \\
\hline $5.4 \%$ & $\%$ & $\%$ & $\%$ & $\%$ & 3.38 & 1.06 \\
\hline 47.7 & 39.4 & & & & & \\
\hline$\%$ & $\%$ & $7.1 \%$ & $3.9 \%$ & $1.9 \%$ & 1.73 & 0.90 \\
\hline 14.6 & 29.1 & 21.5 & 23.4 & 11.4 & & \\
\hline$\%$ & $\%$ & $\%$ & $\%$ & $\%$ & 2.88 & 1.25 \\
\hline 34.4 & 40.8 & & & & & \\
\hline$\%$ & $\%$ & $7.6 \%$ & $9.6 \%$ & $7.6 \%$ & 2.15 & 1.22 \\
\hline
\end{tabular}

occur if I resign my occupation at

this firm without an alternative

job.

$\% \quad \%$

Source: Research Data (2019)

\section{Hypothesis Testing}

$\mathrm{H}_{0}$ : Employees Commitment causes no significant mediating influence on the relationship between Participatory Management and Employees' Performance in selected water service providers in Murang'a County, Kenya .

To test the mediating influence of employees commitment on the relationship between participatory management and employees' performance in water service providers in Murang'a County, Kenya. The study fitted 4 models step wise as suggested by Baron \& Kenny (1986). The study postulated models $1,2,3$ and 4 which were examined in four steps.

\section{Step One: Participatory Management Predicting Employees' Performance}

In the first step, the study fitted a base model to test whether participatory management $(X)$ which is a composite of the independent variables predicted employees' performance $(\mathrm{Y})$ as shown:

$Y=\beta 0+\beta 1 X+\varepsilon$ Model 1

As shown in Table 6, The F-statistic was 208.075 and p-value was 0.000 which shows that the model was statistically significant. Regression coefficient results also show that participatory management composite hold $(\beta=0.003, p$-value $=0.000$ denoting participatory management (consultative management, quality circles, representative participation and delegation) significantly predicted employees' performance.

Table 6: Step One in Testing for Mediating Effect of Employees Commitment

\begin{tabular}{lllllll}
\hline Step 1 & & B & Std. Error & Beta & t & Sig. \\
\hline Model 1 & (Constant) & 3.14 & 0.059 & & 53.193 & 0.000 \\
& Participatory management & 0.003 & 0.000 & 0.76 & 14.456 & 0.000 \\
\hline R square & 0.760 & & & & & \\
Adjusted R Square & 0.577 & & & & & \\
F Statistic & $208.969,(p=0000)$ & & & & & \\
\hline
\end{tabular}

a Dependent Variable: Employees' Performance

Source: Research Data (2019)

$Y=3.14+0.003 X+\varepsilon$ 
$Y=$ Employees' Performance

$X=$ Participatory Management composite

$\varepsilon=$ Error term

\section{Step Two: Participatory Management Predicting Employees commitment}

In the second step, the study fitted a model to test whether participatory management composite $(\mathrm{X})$ predicted employees commitment $(\mathrm{M})$ as shown:

$M=\beta 0+\beta 1 X+\varepsilon$ Model 2

As shown in Table 7, The F-statistic was 95.075 and $\mathrm{P}_{-}=0.000$ indicating model to be significant. Regression coefficient results also show that participatory management composite confirmed $\beta=0.002, p$-value $=0.000$, denoting that participatory management composite significantly predicted employees commitment.

Table 7: Second Step in Testing for Mediating Effect of Employees Commitment

\begin{tabular}{lllllll}
\hline Step 2 & & B & Std. Error & Beta & t & Sig. \\
\hline Model 2 & (Constant) & 2.726 & 0.061 & & 44.734 & 0.000 \\
& Participatory Management & 0.002 & 0.001 & 0.617 & 9.751 & 0.000 \\
R square & 0.617 & & & & & \\
Adjusted R Square & 0.380 & & & & & \\
F Statistic & $95.075,(p=0.000)$ & & & & \\
\hline
\end{tabular}

a Dependent Variable: Employees Commitment

Sources: Research Data (2019)

$M=2.726+0.002 X+\varepsilon$

$X=$ Participatory Management composite

$M=$ Employees Commitment

$\varepsilon=$ Error term

\section{Step Three: Employees Commitment Predicting Employees' Performance}

In step three this study fitted a model confirming employees commitment (M) predicted employees' performance $(\mathrm{Y})$ as shown:

$Y=\beta 0+\beta 1 M+\varepsilon$ Model 3

As shown in Table 8, p-value was 0.000 which shows that the model was statistically significant. Outcomes in regression coefficient results indicate that employees commitment ensured $\beta=0.628, P$ - values $=0.000$, denotation employees commitment significantly predicted employees' performance.

Table 8: Step Three in Testing for Mediating Effect of Employees Commitment

\begin{tabular}{lllllll}
\hline Step 3 & & B & Std. Error & Beta & t & Sig \\
\hline Model 3 & (Constant) & 1.869 & 0.262 & & 7.129 & 0.000 \\
& Employee Commitment & 0.628 & 0.08 & 0.536 & 7.887 & 0.000 \\
\hline R square & 0.536 & & & & & \\
Adjusted R Square & 0.288 & & & & & \\
F Statistic & $62.202,(p=0.000)$ & & & & \\
\hline
\end{tabular}

a Dependent Variable: Employees' Performancee

Sources: Research Data (2019)

$Y=1.869+0.628 M+\varepsilon$

$Y=$ Employees' Performance 
$M=$ Employees Commitment

$\varepsilon=$ Error term

\section{Step Four: Participatory Management; Employees Commitment Predicting Employees' Performance.}

In the final step, the study fitted a model to test whether participatory management composite $(\mathrm{X})$ as well as employees commitment $(\mathrm{M})$ predicted employees' performance $(\mathrm{Y})$ as shown:

$Y=\beta 0+\beta 1 X+\beta 2 M+\varepsilon$ Model 4

As shown in Table 9, F-statistic $=107.158(p=0.000)$ confirmed that participatory management composite and employees commitment significantly predicted employees' performance. The outcomes from regression coefficient also indicate participatory management contained $\beta=$ $0.003,(p$-value $)=(0.000)$ significantly predicted employees' performance while employees commitment $(\beta=0.131, p$-value $=0.094)$ insignificantly predicted employees' performance.

Table 9 : Step Four in Testing for Mediating Effect of Employees Commitment

\begin{tabular}{lllllll}
\hline Step 4 & & B & Std. Error & Beta & t & Sig. \\
\hline Model 4 & (Constant) & 2.783 & 0.22 & & 12.637 & 0.000 \\
& Participatory Management & 0.003 & 0.001 & 0.69 & 10.371 & 0.000 \\
& Employees Commitment & 0.131 & 0.078 & 0.112 & 1.685 & 0.094 \\
R square & 0.765 & & & & & \\
Adjusted R Square & 0.585 & & & & & \\
F Statistic & 107.158, $(p=0.000)$ & & & & \\
\hline
\end{tabular}

a Dependent Variable: Employees' performance

Sources: Research Data (2019)

$Y=2.783+0.003 X+0.131 \mathrm{M}+\varepsilon$

$Y=$ Employees' Performance

$X=$ Participatory Management composite

$M=$ Employees Commitment .

$\varepsilon=$ Error term

Table 10: Summary of Mediation Test

\begin{tabular}{lccc}
\hline Model & Step & Result & Conclusion \\
\hline$Y=3.14+0.003 X+\varepsilon$ & 1 & $\mathrm{P}<0.05$ & Significant \\
$M=2.726+0.002 X+\varepsilon$ & 2 & $\mathrm{p}<0.05$ & Significant \\
$Y=1.869+0.628 M+\varepsilon$ & 3 & $\mathrm{p}<0.05$ & Significant \\
$Y=2.783+0.003 X+0.131 M+\varepsilon$ & 4 & $\mathrm{p}>0.05$ & Insignificant
\end{tabular}

Source: Research Data (2019)

From the results in Table 5, the results show that the effect of participatory management on employees' performance remained significant even when employees' commitment was enjoined model predicting employees' performance. Based on this, the current study rejected null hypothesis that employees commitment has no significant mediating effect on the relationship between participatory management and employees' performance in water service providers in Murang'a County, Kenya.

The study concludes that employees commitment failed to influence mediating interaction amongst the two variables participatory management and employees' performance. 
According to this results, the implication was that participatory management would increase performance in organisation regardless of the employees commitment. The findings were inconsistent with Topolnytsky (2002) who found an advanced connection between affective commitment and employees' performance. On the same note, the finding failed to agree with Hakim (2015) which established that employees commitment is a significant component in increasing service delivery whereas the finding agrees with Poksinska (2002) who found no evidence that employees commitment promotes participatory management.

Summarized outcomes on tests per hypothesis is presented in Table 11 below.

Table 11 : Overall Summary of Test of Hypothesis

\begin{tabular}{|l|l|l|}
\hline Hypothesis & Analysis Results & Conclusion \\
\hline Ho6: Employees Commitment causes no & No mediation observed & Failed to reject \\
significant mediating influence on the & & $\mathrm{H}_{06}$ \\
relationship between Participatory & \\
Managements and Employees' Performance & \\
in selected water service providers & & \\
Murang'a County, Kenya. & & \\
\hline
\end{tabular}

Source: Researcher (2019)

\section{Summary, Conclusion and Recommendations}

The main purpose of this study was to investigate the mediating effects of employees commitment on the relationship between participatory management and employees' performance. At the same time the study revealed that employees commitment had no mediating effect on the relationship between participatory management and employees' performance in selected water service providers in Murang'a County, Kenya. According to the results tabulated the study finally concludes that employees commitment failed to mediate the relationship between participatory management and employees' performance. Employees commitment therefore played insignificant part in enhancing effectiveness of participatory management to enhance employees' performance. The study recommends water service providers in Murang'a County to engage more in these practices as participatory management positively and significantly affects performance of employees. The study recommends water service providers in Murang'a County to focus more on these practices for the purpose of enhancing employees' performance. Evidence that employees commitment partially mediates the relationship between participatory management and employees' performance is a call to the management of water service providers in Murang'a County, Kenya to institute programmes that will ensure employees are committed to the job and organization as this is vital in enhancing effectiveness of participatory management. The study concludes that commitment is positively and significantly affected to both affective and continuous commitment. It suggests if supervisors contemplate, motivate, assist to solve problems, and fight welfare for their subordinates, it can generate optimistic commitment and further promote employees performance. Also, supervisors can continuously upsurge commitment by providing rewards to induce employees to work hard. According to the study commitment has a positive effect contribution on job performance. It reveals that employees are willing to stay and devote themselves to accomplishing job objectives because they have the same values and goals within the organization. Commitment positively and significantly affected to employees performance but failed to show commitment had significant relationship between participatory management and employees. 


\section{References}

Aosa, E. (2011). "The Influence of the External Environment on the performance of Publicly Quoted Companies in Kenya. Journal of Business Administration (1) (7), 205-218.

Allen, R., Ericksen, J., \& Collins, J. (2013). Human resource management, employee relationships, and performance in small businesses. Human Resource Management,52(2), 153-173.

Armstrong, M. (2006) .A Handbook of Human Resource Management Practice. 10th Edition, Kogan Page Publishing, London.

Aronowitz, S., De Smet, A., \& McGinty, D. (2015). Getting organizational redesign right. McKinsey Quarterly, 1-7.

Barney, J. B. (2007). 'Is the resource-based 'view' a useful perspective for strategic management? research? Academy of Management Review, 1 (26), 102-105.

Baron, R., \& Kenny, D. (1986). The Moderator Mediator Variable Distinction in Social Psychological Research: Conceptual, Strategic, and Statistical Consideration. Journal of Personality and Social Psychology, 1 (51), 1173-1182.

Boeddeker, C. (2011). Leadership, Culture and Management Practices of High Performing Workplaces in Australia. Society for Knowledge. Economics, Journal, Sydney, Australia, 2011.

Bryson, A., \& Freeman, R. B. (2012).Employee perceptions of working conditions and desire for worker representation in Britain and the U.S. Springer Science and Business Media.J Labor Res LLC 2012.

Bush, T. (2007). Educational leadership and management: theory, policy, and practice. South African Journal of Education, 27 (3),56-84.

Cardy, R. L. (2014). Performance management: Concepts, skills, and exercises. Armonk, NY: M. E. Sharpe.

Chen, Y. F., \& Tjosvold, D. (2011). Participative leadership by Western managers in China: The role of relationships. Journal of Management Studies, 52,1727-1752

Cooper, D., \& Schindler, P. (2011). Business Research Methods. 11th Edition, McGraw Hill, Boston.

David, A. (2014). A Review 'Supremely elegant lead performance' An International Journal of management,62(5),120-138.

Davis, K. (1967). Human relations at work: The dynamics of organizational behavior. 9th ed., New York: McGraw-Hill.

Devaro, J. (2008). The effects of self-managed and closely managed teams on labor productivity and product quality: An empirical analysis of an establishments. Industrial Relations 47, 659-767.

Elnaga, A., \& Imran, A. (2013). The effect of training on employee performance. European Journal of Business and Management, 5(4), 137-147.

Frese, M., \& Sonnentag, S. (2011). High performance: An action theory approach. Working paper. University of Giessen and University of Konstanz.

Fotopoulos, C., \& Kafetzopoulos, D. (2012). "Critical factors for effective implementation of ISO in SME service firms", Managing Quality management Practices Journal, (20) (5) 440-57.

Ghauri, P., \& Gronhaug, K. (2005).Research Methods in Business Studies.A practical Guide.( $3^{\text {rd }}$ ed.). England: Pearson Education 
Kagaari, J., Munene, J. C., \& Ntaayi, J. M. (2010). Performance management practices, employee attitudes and managed performance. International Journal of Educational Management, 24(6), 507-530.

Hakim, A. (2015). Effect of Organizational Culture, Organizational Commitment to Performance: Study in Horpiral of District South Konawe of Southeast Sulawesi. The International Journal of Engineering and Science, 4. (5) ,33-41.

Hamm, B. (2011).A Human Rights Approach to Development. Human Rights Quarterly, 23, 1005-31.

Hitt, M. A., Ireland, R. D., Camp, S. M., \& Sexton, D. L. (2011).Strategic entrepreneurship: Entrepreneurial strategies for wealth creation. Strategic Management Journal, 22(7), 479-49

Hopkins, A. (2011).Risk-management and rule-compliance: Decision-making in hazardous industries. Safety Science, 49, 110-120.

Jena, P., \& Rautaray, B. (2010). Participative management in medical college libraries of Orissa: a comparative study. Library Review, 5(3), 10-16.

Kashefi, M., Adel, R., Abad, H., \& Nadimi, G. (2013). Organizational commitment and its effects on organizational performance. Interdisciplinary Journal of Contemporary Research in Business, 4(12), 501-510.

Kasomo, D. (2006). Research methods in Humanities and Education. (Statistic, Measurement Evaluation and Testing.) Egerton, Kenya: Egerton University Press.

Katz, D., \& Kahn, R. (1966). The Social Psychology of Organizations (2nd ed.). New York: Wiley.

Kumar, M., Kee, F. T., \& Manshor, A. T. (2009). Determining the relative importance of critical factors in delivering service quality of banks; An application of dominance analysis in servqual model, Managing Service Quality, 19 (2), 211-228.

Lambert, E. G., Hogan, N. L., \& Keena, L. D. (2015). The Impact of Job Attitudes on Private Correctional Staff's Continuance and Affective Organizational Commitment. Journal of Applied Security Research, 10(1), 1-22.

Lau, E. W. (2011).The Effect of Employee Engagement on Continuance and Normative Commitment to the Organization. Southwest Decision Sciences Institute 42nd Annual Conference. Houston, TX.

Mawia, M. J. (2017).Influence of firm features on execution of water reforms in eastern region Kenya. International Journal of Commerce and Management 5 (4),56-66.

Memari, N., Mahdieh, O., \& Marnani, A. B. (2013). The impact of Organizational Commitment on Employees Job Performance. A study of Meli bank. Interdisciplinary Journal of Contemporary Research in Business, 5(5), 164-171.

Moraa, H., Otieno, A., \& Salim, A. (2012). Water Governance in Kenya: Ensuring Accessibility, Mugenda, O. M., \& Mugenda, A. G. (2008).Research Methods. Quantitative and Qualitative Approaches. Nairobi:Acts Press.

Newsrom, J. W. (2011).Organizational Behavior: Human Behavior at work.(13th ed.). New York:McGraw Hill international.

Osman, I. (2011).The relationship between humanresource practices and firm performance: an empirical assessment of firms in Malaysia. Business strategy series, 12(1).

Pritchard, K. (2008). Employee engagement in the UK: meeting the challenge in the public sector. Development and Learning in Organisations, 22(6),15-17.

Robert, J. H. (2011). The Relationship Among Participative Management Style Strategy Implementation Success and Financial Performance In The Food Service Industry. .International Journal of Contemporary Hospital Management, 23(6), 719-738. 
Mwita, J. I. (2012). Performance management model: A system-based approach to system quality. The International Journal of Public Sector Management, (13) (1), 19-37.

Njanja, L. W., Maina, R. N., Kibet, L. K., \& Njagi, K. (2013). Effect of Reward on Employee Performance: A Case of Kenya Power and Lighting Company Ltd., Nakuru, Kenya. International Journal of Business and Management, 8(21), 41.

Noah, Y. (2008). A study of worker participation in management decision making within selected establishments in Lagos, Nigeria. Journal of Social Science, 17(1), 31-39.

Ngatia, Z. M. (2014). The Influence of Non-Monetary Rewards on Employee Performance in Muranga Water and Sanitation Company, Murang'a County. A Master's Thesis.

Orodho, A. (2009). Elements of education research methods. Nairobi: Masola Publishers.

Penrose, E. T. (1959). The Theory of the Growth of the Firm. New York: Wiley.

Poksinska, B., Dahlgaard, J. J., \& Antoni, M. (2002). "The state of ISO certification: a study of Swedish organizations", The TQM magazine, 14 (5), 297-306.

Ruokolainen, M. (2011). Do Organizational and Job-Related Factors Relate to Organizational Commitment? A Mixed Methodology Study of the Associations. University of Jyväskylä. Studies in Education, Psychology and Social Research. Academic dissertation.

Salim, M. B. (2017). The Influence of Organizational Commitment on Omani Employees' Work Performance. International Review of Management and Marketing, 7(2), 151-160.

Saunders, M., Lewis, P., \& Thornhill, A. (2003). Research Methods for Business Students, Harlow UK:.Pearson Education Limited.

Sekaran, U., \& Bougie, R. (2013). Research Methods for Business: A Skill-Building Approach. (6th Ed.). Wiley, New York.

Tohidi. H. (2010). Teamwork productivity \& effectiveness in an organization base on rewards, leadership, training, goals, wage, size, motivation, measurement and information technology, Procedia Computer Science 3,1137-114.

Topolnytsky, L., John, P. M., David, J. S., \& Lynne, H. (2002). Affective, Continuance, and Normative Commitment to the Organization: A Meta-analysis of Antecedents, Correlates, and Consequences, Journal of Vocational Behavior, 61(1), 20-52.

Wernerfelt, B. (2004). A Resource- Based View of the Firm. Strategic Management Journal, 5 ( 2), 171-180

Yang, H. (2008). Efficiency and subjective performance pay. Economic Inquiry,46(2),179-196.

Zeithml, H., Valarie, M., \& Berry, S. (1985) Servqual Model: Concepts and Research Agenda, European Journal Of Marketing, 30 (10), 8-32.

Water Services Regulatory Board. (2015). Impact Report, A Performance Review of Kenya's Water Services Sector -Issue No.7-2015.

Wasreb Impact Report. (2017/2018). A Performance Review of Kenya's Water Services SectorIssue No.10. 